\title{
ULGA NA B+R - OCENA ZMIAN W ZAKRESIE PODATKOWEGO WSPARCIA DZIAŁALNOŚCI INNOWACYJNEJ W POLSCE
}

\begin{abstract}
Streszczenie
Cel - celem niniejszego opracowania jest ukazanie podatkowych instrumentów wsparcia jako istotnego elementu polityki innowacyjnej państwa oraz analiza zmian w poziomie pośredniego wsparcia działalności innowacyjnej, jakie zaszły w polskim systemie podatkowym w wyniku zastąienia ulgi na nowe technologie ulga na badania i rozwój. Metodologia badania - została przeprowadzona symulacja możliwości zmniejszenia kosztów działalności innowacyjnej dostępnych dla typowego przedsiębiorstwa w przypadku ulgi na nowe technologie oraz ulgi na badania i rozwój. Jako materiał źródłowy posłużyły dane statystyczne pochodzące z Głównego Urzędu Statystycznego oraz przepisy prawne dotyczące obu instrumentów wsparcia. Wynik - dzięki analizie literatury uzasadniono istotność stosowania podatkowych instrumentów wsparcia w ramach polityki innowacyjnej. Na podstawie analizy danych i przedstawionych rozważań należy stwierdzić, że ulga na badania i rozwój charakteryzuje się wyższym poziomem pośredniej partycypacji państwa w ogólnych kosztach działalności innowacyjnej przedsiębiorstw niż ulga na nowe technologie. Oryginalhośc/ wartość - z racji narastającej roli innowacyjności w kształtowaniu wzrostu i rozwoju gospodarczego, wsparcie sektora prywatnego w kreowaniu innowacji staje się jednym z ważniejszych elementów polityki gospodarczej. Zasadnicza jest zatem analiza i ocena funkcjonujących instrumentów wsparcia i zmian, jakie zachodzą w tym zakresie. $Z$ uwagi na liczne zastrzeżenia do istniejącego systemu wsparcia działalności innowacyjnej w Polsce, a także dynamiczne zmiany w tym zakresie, $\mathrm{w}$ artykule podjęto bardzo aktualny temat.
\end{abstract}

Słowa kluczowe: innowacja, innowacyjność, polityka innowacyjna, podatkowe instrumenty wsparcia, taxexpenditures

\section{R\&D RELIEF: ASSESSMENT OF CHANGES IN TAX SUPPORT FOR INNOVATION ACTIVITY IN POLAND}

\section{Summary}

The purpose of the paper is to show tax support instruments as a significant element of the innovation policy of the country and to analyze changes at the level of indirect support for innovation activity that took place in the Polish tax system as a result of replacing the relief on new technologies with a relief on research and development. The research methodology involves a simulation of capabilities to reduce the costs of innovation activity available to a typical enterprise in the case of the relief on new technologies and the new relief on research and development. Statistical data from the Central Statistical Office and legal provisions relating to both instruments of support serve as a source material. Based on the analysis of the literature, the significance of using tax instruments as part of innovation policy is justified. On the basis of data analysis, it 
should be stated that the relief on research and development is characterized by a higher level of indirect participation of the state in the general costs of innovation activity of enterprises than the relief on new technologies. Because of the increasing role of innovation in economic growth, the support of the private sector in creating innovation is becoming one of the most important elements of economic policy. Therefore, analysis and assessment of the functioning instruments of support and changes that occur in this field are important. The subject of the paper seems particularly up-to-date as numerous objections have been raised against the existing innovation support system in Poland and the dynamic changes in this regard.

Key words: innovation, innovativeness, innovation policy, instruments of tax policy, tax expenditures

JEL: 038

\section{Wstęp}

Innowacyjność gospodarki jest coraz częściej wymieniana jako jeden z głównych czynników, który determinuje tempo wzrostu i rozwoju gospodarczego. Dlatego też polityka innowacyjna stała się w ostatnich latach istotnym elementem polityki gospodarczej prowadzonej przez wiele krajów i organizacji międzynarodowych. Wyrazem znaczenia polityki innowacyjnej jest uzględnienie stworzenia gospodarki opartej na wiedzy i innowacji jako jednego z głównych celów strategii „Europa 2020”, będącej podstawowym dokumentem w zakresie kierunków rozwoju Unii Europejskiej w latach 2010-2020 [Europa 2020..., 2010, s. 13-16]. Również w Polsce wspieranie kreowania innowacji przez państwo stanowi kluczowy element debaty publicznej. Szczególnie interesującą formą pomocy państwa są podatkowe instrumenty wsparcia, które w Polsce nie cieszą się popularnością wśród przedsiębiorców. Aktualność tematu potwierdzają zmiany, jakie dokonały się dzięki podatkom na przełomie 2015 i 2016 roku w ramach polskiego systemu wpierania innowacyjności.

Celem niniejszego opracowania jest ukazanie podatkowych instrumentów wsparcia jako zasadniczego elementu polityki innowacyjnej państwa oraz analiza zmian w poziomie pośredniego wsparcia działalności innowacyjnej, jakie zaszły w polskim systemie podatkowym w wyniku zastapienia ulgi na nowe technologie ulga na badania i rozwój. Badanie przeprowadzone w ramach niniejszego opracowania miało na celu zweryfikowanie słuszności hipotezy traktującej, że ulga na B+R charakteryzuje się większym stopniem partycypacji państwa w ogólnych kosztach działalności innowacyjnej przedsiębiorstw w stosunku do ulgi na nowe technologie.

Weryfikacji hipotezy posłużyła symulacja możliwości zmniejszenia kosztów działalności innowacyjnej dostępnych dla typowego przedsiębiorstwa w przypadku ulgi na nowe technologie oraz ulgi na B+R. Na podstawie wysokości względnej partycypacji państwa w kosztach dokonano oceny korzyści dotyczaccych skorzystania z każdej z tych ulg. Po czym, dzięki oszacowaniu udziału kosztów objętych daną ulgą w wysokości ogólnych nakładów na działalność innowacyjna, ustalono poziom względnej partycypacji państwa w kosztach działalności innowacyjnej statystycznego przedsiębiorstwa. W celu jak najlepszego odzwierciedlenia stanu faktycznego decydującego o wysokości odliczenia przysługującego poszczególnym przedsiębiorstwom, dane zostały przeanalizowane w odniesieniu do sek- 
tora MŚP i pozostałych przedsiębiorstw. Jako materiał źródłowy posłużyły dane statystyczne pochodzące z Głównego Urzędu Statystycznego oraz przepisy prawne dotyczące obu instrumentów wsparcia.

\section{Podatkowe instrumenty wsparcia działalności innowacyjnej i ich miejsce w polityce innowacyjnej państwa}

Jednym z głównych celów polityki państwa jest wzrost i rozwój gospodarczy, który w znacznej mierze jest determinowany przez potencjal innowacyjny gospodarki. Powiększanie tego potencjału staje się zatem jednym z nadrzędnych celów każdego kraju. Narzędziem realizacji tego celu jest prowadzenie odpowiedniej polityki innowacyjnej przez rząd. Natomiast przez pojęcie polityki innowacyjnej należy rozumieć świadome i celowe działania organów władzy państwowej, skierowane w stronę wspierania, bezpośrednio lub pośrednio, kreowania innowacji i rozwoju innowacyjności w gospodarce, które w konsekwencji powinny zaowocować wzrostem konkurencyjności gospodarki na arenie międzynarodowej oraz przyspieszeniem tempa rozwoju gospodarczego [Ciok, 2009, s. 119-120].

Działania rządów w zakresie kształtowania potencjału innowacyjnego moga przybierać różne formy w zależności od celów przed nimi stawianych, a także stopnia ingerencji rządu w proces tworzenia innowacji. Zasadniczo można wyróżnić dwa aspekty działalności państwa poprzez politykę innowacyjną. Mogą one mieć charakter bezpośredni bądź pośredni. W pierwszym przypadku państwo aktywnie angażuje się w proces powstawania innowacji za sprawą wydatków na działalność innowacyjną, współudziału w kosztach ponoszonych przez sektor prywatny, jak również ustanawianie odpowiednich instytucji mających wspierać kreowanie innowacji. Z kolei pośrednie formy polityki innowacyjnej obejmuja odpowiednie kształtowanie środowiska: prawnego, gospodarczego i politycznego, które będzie motywowało przedsiębiorstwa do kreowania innowacji [Zegarowicz, 2016, s. 32].

Instrumenty wspierania innowacji i innowacyjności można przedstawić w podziale rodzajowym oraz podzielić na bezpośrednie i pośrednie (tabela 1.). Przy wyodrębnieniu poszczególnych grup instrumentów jako główne kryterium posłużył stopień zaangażowania funduszy publicznych w tworzenie danego instrumentu. Za instrumenty bezpośrednie uznano te, $z$ których funkcjonowaniem sa związane konkretne i celowe wydatki z budżetu państwa. Natomiast pośrednimi można nazwać te formy wsparcia, które nie wiążą się z intencjonalnymi nakładami, lecz także istotnie przyczyniają się do rozwoju innowacyjności w kraju. Na bezpośrednie formy wspierania innowacji składaja się narzędzia: finansowe, organizacyjne (instytucjonalne), infrastrukturalne i strukturalne. Do pośrednich zaś można zaliczyć instrumenty prawne i handlowe [Zegarowicz, 2016, s. 32]. 
TABELA 1.

Podział narzędzi polityki innowacyjnej ze względu na charakter i rodzaj stosowanego instrumentu

\begin{tabular}{|c|c|c|}
\hline $\begin{array}{l}\text { Charakter } \\
\text { instrumentu }\end{array}$ & $\begin{array}{c}\text { Rodzaj } \\
\text { instrumentu }\end{array}$ & Instrumenty \\
\hline \multirow{4}{*}{ Bezpośredni } & Finansowe & $\begin{array}{l}\text { Granty, dotacje, kredyty, pożyczki, gwarancje i porę- } \\
\text { czenia }\end{array}$ \\
\hline & $\begin{array}{l}\text { Instytucjonalne } \\
\text { (organizacyjne) }\end{array}$ & $\begin{array}{l}\text { Instytucje świadczące usługi z zakresu: szkoleń, do- } \\
\text { radztwa, transferu technologii, nawiązywania kontak- } \\
\text { tów, udzielania informacji, biblioteki }\end{array}$ \\
\hline & Infrastrukturalne & $\begin{array}{l}\text { Parki technologiczne, inkubatory przedsiębiorczości, } \\
\text { centra innowacji i transferu technologii, sieć pomocy } \\
\text { technicznej dla małych i średnich przedsiębiorstw }\end{array}$ \\
\hline & Strukturalne & $\begin{array}{l}\text { Kształcenie na różnych poziomach, programy ba- } \\
\text { dawcze krajowe i międzynarodowe }\end{array}$ \\
\hline \multirow[t]{2}{*}{ Pośredni } & Prawne & $\begin{array}{l}\text { Tworzenie odpowiedniego ustawodawstwa (w tym po- } \\
\text { datkowego), kontrola monopoli, ochrona własności in- } \\
\text { telektualnej }\end{array}$ \\
\hline & Handlowe & $\begin{array}{l}\text { Umowy handlowe, cła, subsydia eksportowe, kontyn- } \\
\text { genty }\end{array}$ \\
\hline
\end{tabular}

Źródło: opracowanie własne na podstawie: [Zuzek, 2014, s. 272].

Najbardziej doraźnymi formami wspomagania inicjatyw innowacyjnych są instrumenty finansowe. Najczęściej stosowanymi ich formami są granty i dotacje, w ramach których państwo przekazuje konkretne sumy na realizację projektów inwestycyjnych. Przez instytucjonalne instrumenty wsparcia innowacji należy rozumieć wszelkie instytucje, które przyczyniają się do rozwoju przedsiębiorczości dzięki doradztwu, szkoleniom, przekazywaniu informacji czy zapewnianiu dostępu do odpowiedniej wiedzy. Ich najważniejszym działaniem jest współpraca z administracją publiczną i organizacjami prywatnymi w celu pobudzania rozwoju gospodarczego kraju i regionu. Instrumenty infrastrukturalne mają stworzyć odpowiednie zaplecze dla przedsiębiorców, szczególnie tych początkujących. Działania moga mieć charakter np.: wynajmowania nieruchomości i infrastruktury technicznej (parki technologiczne), kompleksowego wsparcia początkujących przedsiębiorców (inkubatory przedsiębiorczości), bezpłatnego przekazywania wyników badań i prac rozwojowych do gospodarki (centra transferu technologii). Z kolei instrumenty strukturalne są celowymi wydatkami z budżetu państwa na badania naukowe oraz kształcenie i rozwój kapitału ludzkiego [Zegarowicz, 2016, s. 33-34].

W ramach instrumentów prawnych państwo w pośredni sposób może przyczyniać się do kształtowania postaw przedsiębiorczych i innowacyjnych. Na pierwszym planie znajdują się tu wszelkiego rodzaju regulacje podatkowe, takie jak: ulgi, zwolnienia lub przesuwanie zapłaty podatku. Podatki są niezwykle istotnym narzędziem ,zachęcania” do innowacji. Odpowiednie regulacje często sprawiaja, że przedsiębiorcy stają się skłonni przeznaczać na inicjatywy innowacyjne spore części zysków, które normalnie byłyby opodatkowane. Inne regulacje także moga przyczynić się do rozwoju innowacyjności. 
Może to być ochrona własności intelektualnej, dzięki której innowatorzy mogą skutecznie zabezpieczać wypracowane pomysły, by uzyskać przewagę konkurencyjną lub czerpać korzyści ze sprzedaży praw i licencji. Zapobieganie powstawaniu monopoli jest również ważnym zadaniem państwa, ponieważ przedsiębiorstwo, które zajmuje na swoim rynku pozycję monopolistyczna, często nie musi dążyć do wzrostu efektywności. Jednocześnie polityka handlowa może służyć wspieraniu innowacyjności przez państwo. W początkowych latach działalności wiele innowacyjnych przedsiębiorstw nie jest w stanie sprostać konkurencji dużo większych, zagranicznych firm. Często w tej sytuacji rząd wprowadza odpowiednie instrumenty, które mają na celu wzmocnić pozycję polskich przedsiębiorstw na arenie krajowej (ograniczenia, cła i kontyngenty) i międzynarodowej (subsydia do eksportu) [Zegarowicz, 2016, s. 34].

Powyższe informacje pokazują, że polityka innowacyjna państwa może przybierać wiele różnorodnych form. Skoro istnieje tyle różnorodnych instrumentów prowadzenia tejże polityki, to zasadniczą kwestią dla badań podjętych w ramach niniejszego opracowania staję się zatem odpowiedź na pytanie: czy i dlaczego podatkowe instrumenty wsparcia działalności innowacyjnej stanowią istotny element, dzięki któremu rządy krajów moga wpływać na poziom innowacyjności gospodarki?

Aby odpowiedzieć na to pytanie, warto zacząć od analizy istoty działania podatkowych instrumentów wsparcia działalności innowacyjnej. Należące do prawnych instrumentów polityki innowacyjnej podatkowe zachęty na innowacje sa zaliczane do grupy preferencji podatkowych określanej mianem tax expenditures. Przez termin ten rozumie się bodźce podatkowe, które będąc odstępstwem od standardowej struktury podatkowej, faworyzuja wybrane: branże, rodzaje działalności lub kategorie podatników w celu realizacji określonych funkcji społeczno-gospodarczych. Jest to grupa preferencji, która szczególnie wyróżnia się wśród ogółu ulg podatkowych. Podczas gdy ulgą podatkową można określić każdy mechanizm zmniejszający podatek, aby dany instrument zakwalifikować do grupy tax expenditures, musi on, oprócz kryterium ilościowego, charakteryzować się specyficznym zestawem cech jakościowych. Za podstawową cechę, która pozwala zakwalifikować instrument do tejże grupy, uznaje się możliwość zastapienia go przez alternatywny program publiczny polegający na bezpośrednim wydatkowaniu środków z budżetu państwa [Dziemianowicz, 2015, s. 35-37].

Podatkowe instrumenty wsparcia innowacji są więc jedną z form partycypacji państwa w kosztach działalności innowacyjnej sektora prywatnego. Jednakże finansowanie tej działalności z budżetu państwa dokonuje się w formie pośredniej poprzez utracone dochody podatkowe. Zarówno bezpośrednie, jak i pośrednie instrumenty polityki innowacyjnej maja za zadanie zwiększać potencjał innowacyjny gospodarki. Jednak należy pamiętać, że każda ingerencja państwa w ramach polityki gospodarczej, oprócz pozytywnych zmian w postaci np. zwiększania poziomu innowacyjności gospodarki, przynosi także szereg negatywnych skutków. To właśnie różnice w poziomie generowanych efektów ubocznych stosowania poszczególnych instrumentów polityki innowacyjnej mogą przesądzać o ostatecznym doborze form pomocy publicznej w ramach tej polityki [Adamczyk, 2013, s. 123].

Wspieranie przez państwo działalności innowacyjnej przedsiębiorstw wywołuje trzy główne rodzaje efektów ubocznych, tj.: efekt substytucji, efekt wypychania oraz efekt 
dyslokacji. Efekt substytucji polega na zastapieniu środków prywatnych funduszami publicznymi w ramach danego projektu inwestycyjnego. W przypadku pojawienia się tego efektu ubocznego przedsiębiorstwa nie podejmują dodatkowej inicjatywy ponad zaplanowane wcześniej działania, pomimo wsparcia ze strony państwa. W następstwie wywołuje to zanikanie zauważalnych efektów polityki innowacyjnej, w tym właśnie przyrostu nakładów na innowacje. Efekt wypychania objawia się z kolei w wypieraniu sektora prywatnego w prowadzeniu działalności innowacyjnej przez sektor publiczny. Rząd, finansując bądź wspierając działalność innowacyjną, zwiększa popyt na czynniki wytwórcze potrzebne do prowadzenia tej działalności, przez co rosna jej koszty. Spada wtedy opłacalność procesu innowacyjnego, a co za tym idzie, także zainteresowanie nim sektora prywatnego. Efekt dyslokacji wynika z zaburzenia rynkowej alokacji zasobów przez ingerencję państwa w proces innowacyjny przedsiębiorstw. Rząd nierzadko wspiera projekty innowacyjne, które cechują się niską efektywnością ekonomiczna. Prowadzi to do zaburzenia warunków konkurencji i przesuwania zasobów do nieefektywnych dziedzin i sektorów [Adamczyk, 2013, s. 123-125].

TABELA 2. Siła negatywnych efektów wykorzystania instrumentów wsparcia działalności innowacyjnej w zależności od rodzaju instrumentu

\begin{tabular}{|c|c|c|c|}
\hline $\begin{array}{c}\text { Rodzaj } \\
\text { oddziaływania }\end{array}$ & Efekt substytucji & Efekt wypychania & Efekt dyslokacji \\
\hline $\begin{array}{c}\text { Instrumenty bezpo- } \\
\text { sredniego finanso- } \\
\text { wania }\end{array}$ & $\begin{array}{c}\text { Zależny od jakości } \\
\text { procesu wyboru } \\
\text { projektów }\end{array}$ & Silny & Silny \\
\hline $\begin{array}{c}\text { Instrumenty po- } \\
\text { średnie (fiskalne) }\end{array}$ & Silny & Słaby & Brak \\
\hline
\end{tabular}

Źródło: [Adamczyk, 2013, s. 125].

Zarówno w odniesieniu do instrumentów bezpośrednich, jak i pośrednich jest możliwe zbadanie nasilenia negatywnych efektów ingerencji państwa (tabela 2.). Silniejszym wpływem efektu substytucji charakteryzują się na ogół zachęty podatkowe z uwagi na charakter pomocy ex post $\mathrm{w}$ stosunku do ponoszenia nakładów przez przedsiębiorstwo. Cecha ta decyduje o dowolności w zakresie wykorzystania przez przedsiębiorców zasobów finansowych zaoszczędzonych dzięki pomocy publicznej. W przypadku finansowania bezpośredniego, środki publiczne muszą być spożytkowane według ustalonych wcześniej reguł. Dzięki temu, przy odpowiedniej jakości procesu doboru projektów kwalifikujących się do otrzymania wsparcia, można ten efekt zminimalizować. Efekt wypychania jest już zdecydowanie bardziej odczuwalny wobec wsparcia bezpośredniego. Jest to uwarunkowane różnicami w rozłożeniu intensywności wsparcia w czasie. Działająca mniej doraźnie i rozłożona na dłuższy okres pomoc w formie pośredniej umożliwia odpowiednie dostosowanie popytu i podaży na rynku czynników wytwórczych niezbędnych w procesie innowacyjnym. Instrumenty bezpośrednie mają niezwykle selektywny charakter i obejmuja swoim działaniem relatywnie niewielka grupe podmiotów, przez co wywołują również silny efekt dyslokacji. Zachęty podatkowe, cechujące 
się znacznie bardziej powszechną formą, praktycznie nie zakłócają rynkowego mechanizmu alokacji i konkurencji, zatem nie powodują negatywnych skutków ubocznych w tym zakresie [Adamczyk, 2013, s. 123-125].

$\mathrm{Z}$ analizy skutków ubocznych ingerencji państwa w proces gospodarczy w ramach polityki innowacyjnej wynika, że instrumenty wsparcia pośredniego generują mniej negatywnych efektów lub efekty te przybierają najczęściej łagodniejszą formę. Nic więc dziwnego, że rządy coraz większej liczby krajów, szczególnie europejskich, starają się do systemów prawnych wprowadzać zachęty podatkowe na działalność innowacyjną [A study ..., 2014, s. 5].

Podatkowe instrumenty wsparcia innowacyjności moga przybierać różne formy, w zależności od: konstrukcji prawnej zachęt, poziomu wsparcia albo etapu procesu innowacyjnego, którego dotyczą. Ze względu na stadium procesu innowacyjnego, którego dotycza preferencyjne przepisy podatkowe, zachęty można podzielić na: instrumenty typu front-end oraz instrumenty typu back-end [Wildowicz-Giegiel, Dziemianowicz, 2015, s. 26].

Instrumenty typu front-end mają za zadanie zachęcać do prowadzenia działalności innowacyjnej dzięki możliwości preferencyjnego potraktowania nakładów wydatkowanych na tę działalność przy ustalaniu zobowiązania podatkowego. Obejmują one zatem początkowe stadium procesu innowacyjnego, jakim jest łożenie nakładów na działalność innowacyjna. Wyróżnia się trzy podstawowe rodzaje zachęt typu front-end:

- zmniejszające podstawę opodatkowania,

- zmniejszające podatek do zapłaty,

- przesuwające płatność podatku w czasie [Wildowicz-Giegiel, Dziemianowicz, 2015, s. 26].

Najczęściej stosowaną grupą są instrumenty polegające na możliwości odliczenia od podstawy opodatkowania określonych wydatków ponoszonych na innowacje. Najczęściej ulgi są oparte na konstrukcji objętościowej, czyli są naliczane od ogółu wydatków kwalifikowanych. Mechanizm taki stosowany jest m.in. w: Belgii, Francji, Holandii, na Litwie, na Weegrzech, w Brazylii i RPA [Worldwide R\&D ..., 2014]. Konstrukcja przyrostowa polega $z$ kolei na obliczeniu wysokości ulgi na podstawie przyrostu wydatków na działalność innowacyjną w stosunku do okresów poprzednich. Wariantem tym posługiwano się np. we Francji w latach 1983-2004 [Bonzio, Irac, Py, 2014, s. 11]. Nierzadko można również spotkać formułę mieszaną opartą na połączeniu dwóch wcześniejszych konstrukcji. Taki sposób naliczania wysokości przysługującego odliczenia wykorzystuje się m.in. w Japonii i Korei Południowej [Worldwide R\&D..., 2014].

Podstawową różnicą zachęt zmniejszających podatek do zapłaty w stosunku do grupy wcześniejszej jest dokonanie odliczenia od wysokości podatku należnego. W tej grupie można równocześnie spotkać zarówno konstrukcję przyrostową stosowaną np. w USA, jak i objętościowa, która obowiązuje od roku 2013 w Wielkiej Brytanii [Worldwide..., 2014]. W ramach tej grupy można także wymienić redukcję stawek lub zwolnienie z obowiązku płacenia ubezpieczeń społecznych i podatków od wynagrodzeń pracowników zaangażowanych w działalność innowacyjna. Instrument ten realizuje się m.in. w Belgii, Holandii i na Węgrzech [Worldwide ReD..., 2014].

Ostatnia grupa preferencji typu front-end polega na przesuwaniu w czasie płatności podatku. Najczęściej występującym instrumentem w tym przypadku jest przyspieszona 
amortyzacja aktywów zużywanych w działalności B+R. Zachętę taka wykorzystuje się m.in. w Belgii, na Litwie, w Brazylii i RPA [Worldwide R\&D..., 2014].

Natomiast instrumenty typu back-end koncentrują się na końcowym stadium procesu innowacyjnego, czyli uzyskiwaniu dochodów. Zawierają się one na preferencyjnym opodatkowaniu (lub nawet zwolnieniu z opodatkowania) dochodów wynikających z prowadzenia działalności innowacyjnej. Najczęściej realizowanymi instrumentami tego typu są pakiety Patent Box oraz Innovation Box, które wiążą się z preferencyjnym traktowaniem dochodów z tytułu: patentów, licencji i praw własności do nowej wiedzy [Wildowicz-Giegiel, Dziemianowicz, 2015, s. 26]. Zachęty tego typu występują m.in. w takich krajach, jak: Francja, Holandia, Weegry i Wielka Brytania [Worldwide RéD ..., 2014].

TABELA 3.

\section{Stopień wykorzystania podatkowych zachęt na działalność innowacyjną w zależności od rodzaju instrumentu}

\begin{tabular}{|c|c|c|c|}
\hline $\begin{array}{c}\text { Grupa instru- } \\
\text { mentów }\end{array}$ & Rodzaj instrumentu & $\begin{array}{c}\text { Liczba } \\
\text { krajów* }\end{array}$ & $\begin{array}{c}\text { Odsetek } \\
\text { krajów* }\end{array}$ \\
\hline \multirow{4}{*}{ Front-end } & Odliczenie od podstawy opodatkowania & 25 & $58 \%$ \\
\cline { 2 - 4 } & Odliczenie od podatku & 22 & $51 \%$ \\
\cline { 2 - 4 } & Niższe składki na ubezpieczenia społeczne & 10 & $23 \%$ \\
\cline { 2 - 4 } & Przyspieszona amortyzacja aktywów B+R & 17 & $40 \%$ \\
\hline \multirow{3}{*}{ Back-end } & Obniżona stawka podatku & 12 & $28 \%$ \\
\cline { 2 - 4 } & Wakacje podatkowe & 11 & $26 \%$ \\
\cline { 2 - 4 } & Zwolnienia podatkowe & 15 & $35 \%$ \\
\hline
\end{tabular}

* W badanej grupie znalazły się 43 następujące kraje: Argentyna, Australia, Austria, Belgia, Brazylia, Kanada, Chile, Chiny, Kolumbia, Czechy, Dania, Francja, Niemcy, Wegrry, Indie, Indonezja, Irlandia, Włochy, Japonia, Litwa, Luksemburg, Malezja, Meksyk, Holandia, Norwegia, Filipiny, Polska, Portugalia, Rumunia, Rosja, Singapur, Słowacja, Słowenia, RPA, Korea Południowa, Hiszpania, Szwecja, Szwajcaria, Tajlandia, Turcja, Wielka Brytania, USA, Wietnam.

Źródło: opracowanie własne na podstawie: [Worldwide R\&D ..., 2014].

Z analizy stopnia wykorzystania poszczególnych typów instrumentów wsparcia (tabela 3.) wynika, że największą popularnością cieszą się odliczenia od podstawy opodatkowania oraz odliczenia od podatku, które w ramach ustawodawstwa podatkowego posiada odpowiednio: 25 i 22 spośród 43 badanych krajów. Zatem tego typu zachęty wykorzystuje odpowiednio: 58\% i 51\% państw objętych analizą. Na przyspieszoną amortyzację aktywów trwałych, zużywanych w związku z prowadzeniem działalności innowacyjnej, swoim podatnikom zezwala 17 terytoriów, co stanowi $40 \%$ badanych jurysdykcji podatkowych. Wśród instrumentów typu back-end najmniejszą popularnością w badanych krajach cieszy się redukcja stawek na ubezpieczenia społeczne wobec do pracowników zaangażowanych w działalność innowacyjna. Tego typu instrumenty posiada w ramach systemu podatkowego 10 z 43 badanych państw (ti. 23\% analizowanych). 
Instrumenty typu back-end nie są tak popularne, jak instrumenty typu front-end. Zachętą tego typu, którą stosuje najwięcej spośród badanych państw, są zwolnienia z opodatkowania niektórych dochodów pochodzących z działalności innowacyjnej. Instrument ten posiada w ramach ustawodawstwa podatkowego 15 jurysdykcji, co stanowi 35\% analizowanych krajów. Zredukowaną stawkę podatku w stosunku do dochodów z działalności innowacyjnej oraz czasowe zwolnienie $z$ obowiązku płacenia podatku od zysków z tejże działalności stosuje odpowiednio: 12 i 11 państw. Tego typu zachęty posiada zatem w systemie podatkowym odpowiednio: $28 \%$ i $26 \%$ analizowanych terytoriów.

\section{Ulga na nowe technologie a ulga na badania i rozwój}

Wsparcie innowacyjności ze strony państwa w Polsce głównie opiera się na instrumentach bezpośredniego finansowania. Dlatego system wspierania innowacji przy pomocy zarówno podatków, jak i wszystkich instrumentów pośrednich nie jest szczególnie rozbudowany. Poszukując preferencji ściśle związanych z innowacyjnością i dostępnych dla sporej części podatników, należałoby wymienić tylko jedno rozwiązanie, którym do końca 2015 roku była ulga na nabycie nowych technologii, funkcjonująca w ramach podatku dochodowego od osób fizycznych (PIT) oraz podatku dochodowego od osób prawnych (CIT). Od 1 stycznia 2016 roku została ona zlikwidowana i zastapiona ulgą na badania i rozwój [Ustawa z dnia 25 wrzéśnia..., 2015].

Zasady korzystania z ulgi na zakup nowych technologii przez podatników zostały uregulowane $\mathrm{w}$ art. 18b Ustany o podatku dochodowym od osób prawnych (u.p.d.o.p.) oraz w art. 26c Ustany o podatku dochodonym od osób fisycznych (u.p.d.o.f.). W myśl Ustany z. dnia 25 wrésnia 2015 roku o zmianie niektórych ustaw w apviazku ze wspieraniem innowacyjności powyższe artykuły zostały uchylone. Według przepisów tej samej ustawy, wprowadzono art. $18 \mathrm{~d}$ i $18 \mathrm{e}$ do u.p.d.o.p. oraz art. 26e, $26 \mathrm{f}$ i $26 \mathrm{~g}$ do u.p.d.o.f., które zawierają unormowania dotyczące zasad korzystania z ulgi na działalność badawczo-rozwojowa.

W przypadku obu instrumentów można wyróżnić zarówno cechy różniące, jak i łączące analizowane przepisy prawne (tabela 4.). Obie ulgi funkcjonują na zasadzie odliczenia od podstawy opodatkowania. Istotną różnica jest rodzaj wydatków, jakie można zaliczyć do podstawy do obliczenia wysokości przysługującego odliczenia. W zlikwidowanej uldze były to wydatki na zakup nowej wiedzy od zewnętrznego podmiotu, więc pobudzała ona jedynie popyt na nowe technologie wypracowane w innych podmiotach, najczęściej placówkach naukowych. Z kolei ulga na $\mathrm{B}+\mathrm{R}$ jako podstawę odliczenia wskazuje wydatki podatnika na jego własną działalność $B+R$, zatem ma za zadanie pobudzać przedsiębiorców do kreowania podaży innowacji we własnym zakresie. Jednak należy pamiętać, że przedsiębiorcy nie mogą swobodnie decydować o tym, które z nakładów na działalność B+R odliczyć od podstawy opodatkowania. Ustawodawca wskazuje w tym przypadku szereg kosztów, które moga być zaliczone do „kosztów kwalifikowanych”. Należą do nich: wynagrodzenia i składki z tytułu tych wynagrodzeń (w części finansowanej przez pracodawcę), nabycie materiałów i surowców, ekspertyzy, opinie, usługi doradcze, nabycie wyników badań naukowych, odpłatne korzystanie $z$ aparatury naukowo-badawczej (z wyłączeniem umów między podmiotami powiązanymi kapitałowo) 
oraz odpisy amortyzacyjne (z wyłączeniem: samochodów osobowych, budowli, budynków i lokali będących odrębną własnościa) [Ustawa z dnia 26 lipca..., 1991, art. 26e; Ustawa z. dnia 15 lutego..., 1992, art. 18d].

TABELA 4.

Ulga na nowe technologie a ulga na $B+R$ - podobieństwa i różnice

\begin{tabular}{|c|c|c|}
\hline Wyszczególnienie & Ulga na nowe technologie & Ulga na badania i rozwój \\
\hline $\begin{array}{l}\text { Charakter instru- } \\
\text { mentu }\end{array}$ & $\begin{array}{l}\text { Odliczenie od podstawy opo- } \\
\text { datkowania }\end{array}$ & $\begin{array}{l}\text { Odliczenie od podstawy opo- } \\
\text { datkowania }\end{array}$ \\
\hline Podstawa odliczenia & $\begin{array}{l}\text { Wydatki poniesione w celu na- } \\
\text { bycia nowej technologii od } \\
\text { podmiotu zewnętrznego }\end{array}$ & $\begin{array}{l}\text { Wydatki poniesione na prowa- } \\
\text { dzenie działalności } \mathrm{B}+\mathrm{R} \text { przez } \\
\text { przedsiębiorstwo }\end{array}$ \\
\hline Wielkość odliczenia & $50 \%$ podstawy & Od $10 \%$ do $30 \%$ podstawy \\
\hline $\begin{array}{l}\text { Podmioty upraw- } \\
\text { nione do skorzysta- } \\
\text { nia z ulgi }\end{array}$ & $\begin{array}{l}\text { Podatnicy opodatkowani po- } \\
\text { datkiem CIT oraz skala podat- } \\
\text { kową w ramach PIT }\end{array}$ & $\begin{array}{l}\text { Podatnicy opodatkowani po- } \\
\text { datkiem CIT oraz skalą podat- } \\
\text { kową i podatkiem liniowym } \\
\text { w ramach PIT }\end{array}$ \\
\hline Wyłączenia & $\begin{array}{c}\text { Podatnicy prowadzacy działal- } \\
\text { ność na terenie SSE }\end{array}$ & $\begin{array}{c}\text { Podatnicy prowadzacy działal- } \\
\text { ność na terenie SSE }\end{array}$ \\
\hline $\begin{array}{c}\text { Czas na skorzystanie } \\
\text { z ulgi }\end{array}$ & $\begin{array}{c}\text { Rok poniesienia wydatków } \\
\text { (lub maksymalnie kolejne trzy } \\
\text { lata) }\end{array}$ & $\begin{array}{c}\text { Rok poniesienia wydatków } \\
\text { (lub maksymalnie kolejne trzy } \\
\text { lata) }\end{array}$ \\
\hline $\begin{array}{l}\text { Utrata prawa do od- } \\
\text { liczenia }\end{array}$ & $\begin{array}{l}\text { Zwrot poniesionych nakła- } \\
\text { dów, upadłość, udzielenie in- } \\
\text { nemu podmiotowi prawa do } \\
\text { nowej wiedzy }\end{array}$ & Zwrot poniesionych nakładów \\
\hline Dodatkowe wymogi & $\begin{array}{c}\text { Potwierdzenie cech nowej } \\
\text { wiedzy przez jednostkę nau- } \\
\text { kowa, zakup udokumento- } \\
\text { wany umowa, zakaz zapłaty } \\
\text { w ramach wkładu niepienięż- } \\
\text { nego }\end{array}$ & $\begin{array}{l}\text { Badania podstawowe prowa- } \\
\text { dzone na podstawie umowy } \\
\text { z jednostką naukowa, odrębna } \\
\text { ewidencja kosztów działalno- } \\
\text { ści B+R }\end{array}$ \\
\hline
\end{tabular}

Źródło: opracowanie własne na podstawie [Zegarowicz, 2016, s. 44].

Kolejną rozbieżnością między nową a starą ulga jest wysokość przysługującego odliczenia. Podczas gdy w uldze technologicznej było to $50 \%$ wydatków zakwalifikowanych do podstawy odliczenia, w natomiast uldze na $\mathrm{B}+\mathrm{R}$ można odliczyć od $10 \%$ do $30 \%$ kosztów kwalifikowanych:

- $\quad 30 \%$ kosztów związanych z wynagrodzeniami pracowników;

- $\quad 20 \%$ pozostałych kosztów zaliczonych do kosztów kwalifikowanych, jeżeli podatnik należy do sektora MŚP;

- $\quad 10 \%$ pozostałych kosztów zaliczonych do kosztów kwalifikowanych w przypadku pozostałych podatników [Ustawa z dnia 26 lipca..., 1991, art. 26e; Ustawa z.dnia 15 lutego..., 1992, art. 18d]. 
Ulga funkcjonująca od 1 stycznia 2016 roku rozszerza zakres podmiotów uprawnionych do skorzystania z pomniejszenia podstawy również na podatników opodatkowanych stawką liniową w PIT. Ulga na nowe technologie dawała taką możliwość jedynie podatnikom opodatkowanym CIT oraz skalą podatkową w ramach PIT.

Obie ulgi wyłączają ze skorzystania z odliczenia podmioty, które prowadzą swoją działalność na terenie specjalnych stref ekonomicznych (SSE). W obu przypadkach ustawodawca zezwala także podatnikowi, w szczególnych okolicznościach, na rozliczenie ulgi maksymalnie do trzech kolejnych lat podatkowych, następujących po roku poniesienia wydatków.

W odniesieniu do ulgi technologicznej ustawodawca wymienia trzy sytuacje, które mogą spowodować utratę prawa do odliczenia przez podatnika. Stanie się tak wówczas, gdy przed upływem trzech lat podatkowych od końca roku podatkowego, w którym wprowadził on nową technologię do ewidencji środków trwałych oraz wartości niematerialnych i prawnych: udzieli innym podmiotom prawa do nowej wiedzy, zostanie ogłoszona jego upadłość (lub zostanie postawiony w stan likwidacji), w jakiejkolwiek formie otrzyma zwrot wydatków, jakie przeznaczył na nabycie nowej technologii [Ustawa z dnia 26 lipca..., 1991, art. 26c; Ustawa z. dnia 15 lutego..., 1992, art. 18b]. W stosunku do ulgi na B+R został postawiony tylko wymóg braku zwrotu poniesionych nakładów.

W przepisach prawnych związanych z korzystaniem z obu ulg ustawodawca dołącza kilka dodatkowych warunków, jakie musi spełnić podatnik kwalifikujący się do skorzystania z preferencji. W uldze na nowe technologie są to: potwierdzenie cech nowej wiedzy przez jednostkę naukowa, zakup udokumentowany umowa, zakaz zapłaty w ramach wkładu niepieniężnego. W przypadku ulgi na $\mathrm{B}+\mathrm{R}$ dodatkowymi wymogami są z kolei: prowadzenie badań podstawowych opartych na umowie z jednostką naukowa i odrębna ewidencja kosztów działalności B+R.

\section{Analiza zmian w poziomie wsparcia działalności innowacyjnej przedsię- biorstw w wyniku zastapienia ulgi na nowe technologie ulgą na $B+R$}

Analizy przepisów podatkowych dotyczących ulgi na nowe technologie i ulgi na $\mathrm{B}+\mathrm{R}$ skłania do konstatacji, że jedną z pierwszych zauważalnych różnic jest wysokość dostępnych odliczeń. Podczas gdy dla ulgi technologicznej wynosiła ona $50 \%$ podstawy odliczenia, w przypadku ulgi na $\mathrm{B}+\mathrm{R}$ wahała się od $10 \%$ do $30 \%$. Nasuwa się zatem pytanie o zasadność zastapienia ulgi technologicznej ulgą na $\mathrm{B}+\mathrm{R}$ w kontekście wsparcia działalności innowacyjnej przedsiębiorstw w Polsce.

W celu weryfikacji hipotezy postawionej w niniejszym opracowaniu i odpowiedzi na powyższe pytanie istotną kwestia jest zbadanie końcowych korzyści dla przedsiębiorstwa wynikających ze skorzystania z obu ulg. Korzyści te są reprezentowane przez odsetek kosztów działalności innowacyjnej przedsiębiorstwa, jakie państwo pośrednio pokrywa za sprawą tax expenditures. 
TABELA 5.

Korzyści wynikające ze skorzystania z ulgi na nowe technologie

\begin{tabular}{|c|c|c|c|}
\hline 1. & $\begin{array}{c}\text { Wysokość nakładów na nabycie nowych } \\
\text { technologii }\end{array}$ & $\begin{array}{c}\text { Formuła } \\
\text { obliczeń }\end{array}$ & $\mathbf{1 0 0 0 0 0 0 ~ z ł ~}$ \\
\hline 2. & Kwota odliczenia & $\mathbf{1 .} * \mathbf{0 , 5}$ & $500000 \mathrm{zl}$ \\
\hline 3. & Stawka podatku CIT & - & $19 \%$ \\
\hline 4. & Wartość preferencji podatkowej & $\mathbf{2 .} * \mathbf{3}$. & $95000 \mathrm{z} 1$ \\
\hline 5. & $\begin{array}{c}\text { Odsetek, o jaki został obniżony koszt nabycia } \\
\text { technologii dzięki preferencji }\end{array}$ & $\mathbf{3 .} / \mathbf{1 .}$ & $\mathbf{9 , 5 \%}$ \\
\hline
\end{tabular}

a Zakłada się, że przedsiębiorstwo jest w stanie dokonać odliczenia w pełnej możliwej wysokości w roku poniesienia wydatków.

Źródło: opracowanie własne.

Kalkulacja względnych korzyści, jakie przedsiębiorstwo mogło odnieść w wyniku skorzystania z ulgi na nowe technologie w ramach podatku CIT, nie jest wysoce złożona (tabela 5.). Wydając na nabycie nowej technologii $1 \mathrm{mln}$ zł, przedsiębiorca miał prawo do dokonania odliczenia od podstawy opodatkowania 50\% tej kwoty, czyli 0,5 mln zł. Przy obowiazzującej w Polsce dziewiętnastoprocentowej stawce CIT, wartość preferencji podatkowej będzie wynosić 95 tys. zł. Natomiast wielkość końcowych korzyści, jakie odnosi przedsiębiorstwo, wyrażona w odsetku kosztów nabycia nowych technologii obniżonym dzięki skorzystaniu z ulgi, stanowi 9,5\%.

W przypadku ulgi na $\mathrm{B}+\mathrm{R}$ kalkulacja korzyści jest już jednak bardziej skomplikowana. Warunkują to różnice w wysokości przysługującego odliczenia w zależności od rodzaju ponoszonego kosztu i wielkości przedsiębiorstwa, które zostały omówione w poprzedniej części artykułu. Aby dokonać kalkulacji korzyści, niezbędne są więc informacje na temat udziału poszczególnych rodzajów wydatków na działalność B+R w ogólnych kosztach tejże działalności w sektorze MŚP i w pozostałych przedsiębiorstwach. Według zaleceń Komisji Europejskiej, podstawowym kryterium wyodrębniania sektora MŚP z ogółu przedsiębiorstw działających w danym kraju powinno być kryterium liczby zatrudnionych [Zalecenie Komisji..., s. 1]. Należy zatem przyjąć, że na podstawie liczby zatrudnionych jest możliwe wyodrębnienie przedsiębiorstw, które zgodnie z przepisami prawnymi dotyczącymi ulgi na $\mathrm{B}+\mathrm{R}$, omówionymi w poprzedniej części artykułu, mają prawo do ustalenia wysokości odliczenia kosztów pozaosobowych według wyższej stawki.

TABELA 6.

Podział przedsiębiorstw ze względu na kryterium wielkości zatrudnienia

\begin{tabular}{|c|c|}
\hline Grupa przedsiębiorstw & Wielkość zatrudnienia \\
\hline Mikro & do 9 osób \\
\hline Małe & od 10 do 49 osób \\
\hline Średnie & od 50 do 249 osób \\
\hline Pozostałe & powyżej 249 osób \\
\hline
\end{tabular}

Źródło: opracowanie własne na podstawie: [Zalecenie Komisji..., 2003, art. 2]. 
Komisja Europejska zaleca podział przedsiębiorstw według kryterium zatrudnienia na: mikro, małe, średnie i pozostałe (tabela 6.). Zgodnie z wytycznymi Komisji, do sektora MŚP należy zaliczyć trzy grupy przedsiębiorstw wymienione w tabeli, tj.: mikro, małe i średnie [Zalecenie Komisji..., 2003, art. 2]. Do grupy tej należą zatem przedsiębiorstwa zatrudniające nie więcej niż 249 osób. Podmioty, których personel przekracza tę liczbę, trzeba z kolei zakwalifikować do przedsiębiorstw pozostałych.

$\mathrm{Z}$ analizy struktury nakładów wewnętrznych na działalność $\mathrm{B}+\mathrm{R}$ przedsiębiorstw o zatrudnieniu do 249 osób w Polsce, w 2014 roku (wykres 1.) wynika, że największą część nakładów w badanych przedsiębiorstwach stanowiły bieżące koszty osobowe, na które przypadało 38\% kosztów. Natomiast pozostałe wydatki bieżące pochłaniały $29 \%$ ogólnych nakładów. Na wydatki bieżące przedsiębiorstwa te łożyły więc $67 \%$ ogólnych nakładów. Inwestycyjne wydatki na środki trwałe wynosiły 33\% nakładów na B+R w przedsiębiorstwach o zatrudnieniu do 249 osób.

Badając strukturę nakładów wewnętrznych na działalność $\mathrm{B}+\mathrm{R}$ przedsiębiorstw o zatrudnieniu powyżej 249 osób (wykres 2.), trzeba stwierdzić, że największą część nakładów stanowiły również bieżące koszty osobowe, na które przypadało 47\% kosztów, czyli o 9 p. p. więcej niż w przypadku przedsiębiorstw o niższym zatrudnieniu. Pozostałe wydatki bieżące pochłaniały $32 \%$ ogólnych nakładów. Na wydatki bieżące przedsiębiorstwa te łożyły $79 \%$ ogólnych nakładów. Inwestycyjne wydatki na środki trwałe w analizowanej grupie przedsiębiorstw objęły $21 \%$ nakładów na B+R. Przedsiębiorstwa o wyższym zatrudnieniu przeznaczały zatem znacznie mniejszą część ogólnych nakładów na działalność $\mathrm{B}+\mathrm{R}$ na inwestycje w środki trwałe.

WYKRES 1.

\section{Struktura nakładów na działalność $\mathrm{B}+\mathrm{R}$ w przedsiębiorstwach o zatrudnieniu do 249 osób w Polsce, w 2014 roku}

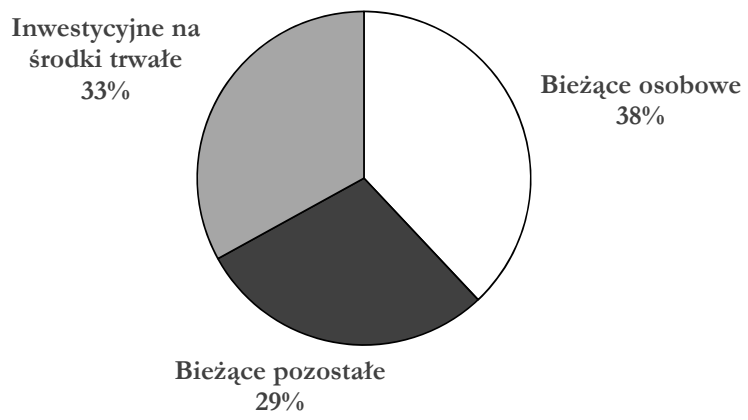

Źródło: opracowanie własne na podstawie danych GUS: [Nauka i technika..., 2014]. 
WYKRES 2.

\section{Struktura nakładów na działalność $B+R$ w przedsiębiorstwach o zatrudnieniu powyżej 249 osób w Polsce, w 2014 roku}

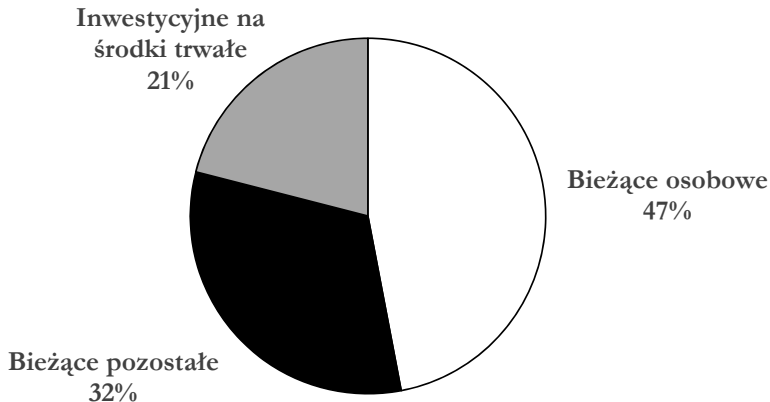

Źródło: opracowanie własne na podstawie danych GUS: [Nauka i technikea..., 2014].

Przyjmując struktury przedstawione na wykresie 1. i wykresie 2. jako proporcje, w jakich rozkładają się koszty działalności B+R typowego przedsiębiorstwa należącego odpowiednio do sektora MŚP oraz do pozostałych przedsiębiorstw, można dokonać kalkulacji korzyści, które mogą odnieść hipotetyczne przedsiębiorstwa należące do badanych grup, korzystając z ulgi na B+R.

TABELA 7.

Korzyści wynikające ze skorzystania z ulgi na $B+R$ w zależności od wielkości przedsiębiorstwa

\begin{tabular}{|c|c|c|c|c|}
\hline 1. & Wielkość przedsiębiorstwa & Formuła obliczeń & MŚP & Pozostałe \\
\hline 2. & Nakłady na $B+R^{a}$, w tym: & - & \multicolumn{2}{|c|}{$1000000 \mathrm{zI}$} \\
\hline 3. & Koszty osobowe & $1 . * \mathbf{a}$ & $380000 \mathrm{zl}$ & $470000 \mathrm{zl}$ \\
\hline 4. & Pozostałe nakłady ${ }^{\mathrm{b}}$ & $1 . * a$ & $620000 \mathrm{zl}$ & $530000 \mathrm{zl}$ \\
\hline 5. & Kwota odliczeniac, w tym: & $6 .+7$. & $238000 \mathrm{zr}$ & $194000 \mathrm{zl}$ \\
\hline 6. & Koszty osobowe & $3 . * 0,3$ & $114000 \mathrm{zl}$ & $141000 \mathrm{zl}$ \\
\hline 7. & Pozostałe nakłady & $\begin{array}{l}\text { MSP: } 4 . * \mathbf{0 , 2} \\
\text { Poz.: } 4 . * \mathbf{0 , 1}\end{array}$ & $124000 \mathrm{zl}$ & $53000 \mathrm{zk}$ \\
\hline 8. & Stawka podatku CIT & - & \multicolumn{2}{|c|}{$19 \%$} \\
\hline 9. & Wartość preferencji podatkowej & 5. $* 8$ & $45220 \mathrm{zl}$ & $36860 \mathrm{zt}$ \\
\hline 10. & $\begin{array}{l}\text { Odsetek, o jaki został obniżony koszt prowa- } \\
\text { dzenia działalności B+R dzięki preferencji }\end{array}$ & 9. / 1. & $4,522 \%$ & $3,686 \%$ \\
\hline
\end{tabular}

a Zakłada się, że nakłady na B+R stanowią koszty kwalifikowane w ramach ulgi, a udział kosztów osobowych i pozostałych nakładów w ogólnej ich wysokości wynosi dla MŚP odpowiednio: $38 \%$ i $62 \%$ oraz dla pozostałych przedsiębiorstw odpowiednio: $47 \%$ i 53\%.

b Przyjmuje się, że na pozostałe nakłady składają się pozostałe koszty bieżące oraz amortyzacja aktywów trwałych.

c Zakłada się, że przedsiębiorstwo jest w stanie dokonać odliczenia w pełnej, możliwej wysokości w roku poniesienia wydatków.

Źródło: opracowanie własne. 
Porównując wysokość względnych korzyści, jakie w wyniku skorzystania z ulgi na $\mathrm{B}+\mathrm{R}$ mogą odnieść typowe podmioty z sektora MŚP i pozostałych przedsiębiorstw (tabela 7.), z danymi na temat korzyści wynikających ze skorzystania z ulgi na nowe technologie (tabela 5.), można wysnuć wniosek, że ulga technologiczna gwarantowała znacznie większe korzyści. Koszt nabycia nowej wiedzy zmniejszał się dzięki tej preferencji o 9,5\%. W przypadku ulgi na $\mathrm{B}+\mathrm{R}$ przeciętne przedsiębiorstwo może zmniejszyć koszt prowadzenia działalności badawczo-rozwojowej o 3,686\% lub 4,522\% w zależności od tego, czy należy do sektora MŚP. Względne korzyści są więc ponad dwukrotnie wyższe na korzyść ulgi technologicznej. Jednak należy pamiętać o tym, że obie ulgi dotyczą innych rodzajów kosztów. Aby dokładnie zbadać końcowe korzyści z nich wynikające, trzeba zatem przeanalizować udział kosztów kwalifikowanych objętych obiema ulgami w ogólnych kosztach działalności innowacyjnej polskich przedsiębiorstw.

WYKRES 3.

\section{Struktura nakładów na działalność innowacyjną w przedsiębiorstwach o zatrudnieniu do 249 osób w Polsce, w 2014 roku}

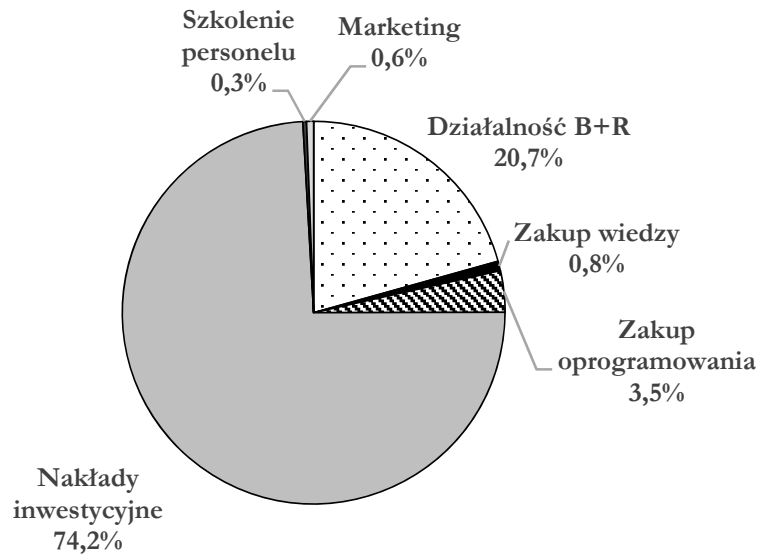

Źródło: opracowanie własne na podstawie danych GUS: [Nauka i technika..., 2014].

Analizując udział poszczególnych rodzajów nakładów na działalność innowacyjną w ogólnych kosztach tejże działalności w firmach z sektora MŚP (wykres 3.) i pozostałych przedsiębiorstwach (wykres 4.), można zauważyć, że w obu grupach największą część wydatkowanych nakładów stanowiły koszty inwestycji w: budynki, budowle, grunty oraz maszyny i urządzenia techniczne. Koszty te objęły $74,2 \%$ w sektorze MSP i $68,1 \%$ w pozostałych przedsiębiorstwach. Działalność $B+R$ była drugim rodzajem wydatków pod względem ich udziału w ogólnych kosztach działalności innowacyjnej i wyniosła odpowiednio: 20,7\% i 22,2\% nakładów dla MŚP i przedsiębiorstw o większym zatrudnieniu. Na nabywanie nowej wiedzy przedsiębiorstwa z sektora MŚP przeznaczały z kolei $0,8 \%$ nakładów na innowacje, podczas gdy dla pozostałych podmiotów udział tego rodzaju 
wydatków kształtował się na poziomie 1,5\%. Pozostałe koszty wynosiły dla MŚP i przedsiębiorstw o większym zatrudnieniu odpowiednio: 4,4\% i 8,2\% nakładów i składały się na nie: zakup oprogramowania, szkolenie personelu związane z działalnością innowacyjna oraz marketing dotyczący nowych lub istotnie ulepszonych produktów.

WYKRES 4.

Struktura nakładów na działalność innowacyjną w przedsiębiorstwach o zatrudnieniu powyżej 249 osób w Polsce, w 2014 roku

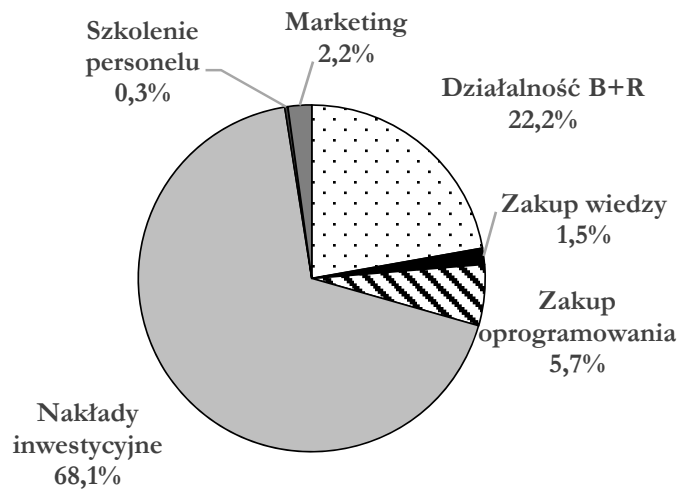

Źródło: opracowanie własne na podstawie danych GUS: [Nauka i tecbnika..., 2014].

TABELA 8.

Poziom partycypacji państwa w kosztach działalności innowacyjnej przedsiębiorstw poprzez ulgę na $B+R$ i ulgę na nowe technologie

\begin{tabular}{|c|c|c|c|c|c|}
\hline 1. & Ulga & \multicolumn{2}{|c|}{ Ulga na B+R } & \multicolumn{2}{|c|}{$\begin{array}{c}\text { Ulga na nowe } \\
\text { technologie }\end{array}$} \\
\hline $\mathbf{2 .}$ & Wielkość przedsiębiorstwa & MŚP & $\begin{array}{c}\text { Pozo- } \\
\text { stałe }\end{array}$ & MŚP & $\begin{array}{c}\text { Pozo- } \\
\text { stałe }\end{array}$ \\
\hline $\mathbf{3 .}$ & Koszty objęte ulgą & \multicolumn{2}{|c|}{ Działalność B+R } & \multicolumn{2}{|c|}{ Zakup nowej wiedzy } \\
\hline $\mathbf{4 .}$ & $\begin{array}{c}\text { Udział kosztów objętych ulgą w ogólnych } \\
\text { kosztach działalności innowacyjnej }\end{array}$ & $20,7 \%$ & $22,2 \%$ & $0,8 \%$ & $1,5 \%$ \\
\hline $\mathbf{5 .}$ & $\begin{array}{c}\text { Odsetek, o jaki został obniżony koszt ob- } \\
\text { jęty ulgą dzięki preferencji }\end{array}$ & $4,522 \%$ & $3,686 \%$ & \multicolumn{2}{|c|}{$9,5 \%$} \\
\hline $\mathbf{6 .}$ & $\begin{array}{c}\text { Odsetek, o jaki zostały obniżone koszty dz. } \\
\text { innowacyjnej dzięki preferencji (4. } * \mathbf{5 .})\end{array}$ & $\mathbf{0 , 9 3 6 \%}$ & $\mathbf{0 , 8 1 8 \%}$ & $\mathbf{0 , 0 7 6 \%}$ & $\mathbf{0 , 1 4 3 \%}$ \\
\hline
\end{tabular}

Źródło: opracowanie własne.

Po przeanalizowaniu udziału poszczególnych nakładów w kosztach ogólnych działalności innowacyjnej polskich przedsiębiorstw można ustalić poziom pośredniej partycypacji państwa w kosztach tejże działalności poprzez preferencje podatkowe, jakie przedsiębiorcy mogą uzyskać dzięki skorzystaniu z ulgi na nowe technologie i ulgi na B+R. Jak wynika $z$ danych zawartych w tabeli 8., nakłady na działalność B+R stanowią 
około jedną piątą ogólnych wydatków na działalność innowacyjną w polskich przedsiębiorstwach, przy czym dla przedsiębiorstw spoza sektora MŚP udział ten jest wyższy o 1,5 p. p. niż dla podmiotów do niego należących. Natomiast zakup nowej wiedzy obejmuje zaledwie $0,8 \%$ lub 1,5\% nakładów w zależności od tego, czy przedsiębiorstwo należy do sektora MSP. Udział nakładów na B+R jest zatem dla MŚP i pozostałych podmiotów odpowiednio: dwudziestosześciokrotnie i piętnastokrotnie wyższy niż udział wydatków na zakup nowej wiedzy. W wyniku takiego rozłożenia poszczególnych rodzajów wydatków na innowacje w polskich przedsiębiorstwach, preferencje uzyskane dzięki uldze na nowe technologie stanowią zaledwie 0,076\% kosztów działalności innowacyjnej w sektorze MŚP. Dla firm o większym zatrudnieniu udział ten jest prawie dwukrotnie wyższy $\mathrm{i}$ wynosi $0,143 \%$. Tymczasem poprzez taxexpenditures, wynikające $\mathrm{z}$ ulgi na $\mathrm{B}+\mathrm{R}$, państwo partycypuje w 0,936\% nakładów na innowacje w przedsiębiorstwach sektora MŚP oraz $0,818 \%$ w pozostałych przedsiębiorstwach. Są to wielkości odpowiednio: dwunastokrotnie i sześciokrotnie wyższe niż w przypadku ulgi na nowe technologie.

Po uwzględnieniu korzyści, jakie dają podatnikom obie ulgi i udziału kosztów nimi objętych w ogólnych kosztach działalności innowacyjnej przedsiębiorstw w Polsce, należy zatem stwierdzić, że ulga na B+R charakteryzuje się znacznie większym stopniem partycypacji państwa w ogólnych kosztach działalności innowacyjnej przedsiębiorstw w stosunku do ulgi na nowe technologie. Pozwala to na pozytywne zweryfikowanie hipotezy badawczej postawionej w niniejszym artykule.

\section{Podsumowanie}

Ulga na nowe technologie nie cieszyła się dużym zainteresowaniem podatników od momentu jej wprowadzenia. Od 2007 roku z ulgi tej korzystało jedynie kilkudziesięciu podatników podatku CIT rocznie ${ }^{1}$. Niewielkie zainteresowanie ze strony podatników postawiło pod znakiem zapytania skuteczność tego instrumentu związaną z zachęcaniem przedsiębiorców do kreowania innowacji. Dlatego też od 1 stycznia 2016 roku zastąpiono ją ulgą na badania i rozwój.

Ulga na $\mathrm{B}+\mathrm{R}$ polega na możliwości odliczenia od podstawy opodatkowania, odrębnej od wydatków na nowe technologie, kategorii działalności innowacyjnej, jaką jest działalność badawczo-rozwojowa. Jak pokazują wyniki przeprowadzonych badań, działalność $\mathrm{B}+\mathrm{R}$ stanowi przeciętnie jeden $\mathrm{z}$ wydatków o największym udziale w kosztach działalności innowacyjnej polskich przedsiębiorstw. Fakt ten sprawia iż, pomimo mniejszych stawek procentowych odliczeń, ulga na $B+R$ umożliwia kilkukrotnie większą partycypację państwa w ogólnych kosztach działalności innowacyjnej reprezentatywnego przedsiębiorstwa.

${ }^{1}$ Według danych Ministerstwa Finansów, z ulgi na nowe technologie w latach 2007-2014 skorzystało maksymalnie 97 podatników CIT w 2011 roku i minimalnie 19 podatników CIT w 2007 roku [Preferencje Podatkowe w Polsce]. 
Doświadczenia państw, które posiadają ulgi na działalność B+R funkcjonujące w ramach podatku dochodowego, pokazuja że instrument ten może być ważnym elementem w budowaniu potencjału innowacyjnego gospodarki. Kraje, takie jak Czechy lub Węgry, poprawiły udział wydatków na B+R w PKB w trakcie ostatniej dekady o odpowiednio: 0,85 i 0,51 p. p. ${ }^{2}$. Oba posiadaja w swoich systemach podatkowych objętościową ulgę na $\mathrm{B}+\mathrm{R}$, polegającą na możliwości dwukrotnego odliczenia kosztów działalności B+R [Worldwide ReD..., 2014]. W związku z tym, wprowadzenie ulgi na $\mathrm{B}+\mathrm{R}$ również w Polsce pozwala na stawianie pozytywnych prognoz w zakresie kształtowania się innowacyjności w naszym kraju w najbliższych latach. Jednak na niekorzyść polskiej ulgi mogą wpłynąć relatywnie niskie stawki odliczeń, które wynoszą zaledwie od 10\% do 30\% kosztów kwalifikowanych.

Interpretując konkluzje płynące z niniejszego artykułu, należy pamiętać, że zastosowana metodologia badawcza odwołuje się do kategorii statystycznego (przeciętnego) przedsiębiorstwa. Wnioski z przeprowadzonego badania są więc reprezentatywne dla ogółu przedsiębiorców w Polsce należących do sektora MSP oraz ogółu firm spoza tej grupy. Zatem nie można wyników analizy odnieść indywidualnie do pojedynczego przedsiębiorstwa, branży lub regionu. Struktury nakładów na działalność B+R i działalność innowacyjną mogą odbiegać od danych przedstawionych w niniejszym opracowaniu, w przypadku zmiany źródła lub zakresu materiału badawczego, co wpłynęłoby na wysokość przysługującego odliczenia i względnych korzyści wynikających ze skorzystania z obu ulg. Warto także zauważyć, że zmiany podatkowe najczęściej nie pozostają bez reakcji ze strony podatników. Oznacza to, że sama zmiana analizowanych przepisów prawnych może oddziaływać na strukturę nakładów na działalność innowacyjną w polskich przedsiębiorstwach, to natomiast może rzutować na wyniki analizy.

\section{Literatura}

Adamczyk A., 2013, Efektywność fiskalna bodżców podatkowych wspierajacych dziatalność badawczo-rozpojowa przedsiebiorstw, Zapol, Szczecin.

A Study on RevD Tax Incentives. Final Report, 2014, Working Paper n. 52 - 2014, Taxation Papers, European Commission, European Union, https://ec.europa.eu/futurium/ en/system/files/ged/28-taxud-study_on_rnd_tax_incentives_-_2014.pdf (data wejścia: 16.11.2016).

Bonzio A., Irac D., Py L., 2014, Impact of research tax credit on R\&D and innovation: evidence from the 2008 French reform, Direction générale des études et des relations internationales, Banque de France.

Ciok S., 2009, Polityka rzqadu wobec wspierania działalności innowacyjnej i badawcro-rozwojowej, [w:] Endo- $i$ egrogeniczne determinanty obszarów wrosostu i stagnaci w województwie dolnoślaskim w kontekście Dolnoślaskeiej Strategii Innowacij, R. Dobrowolska-Kaniewska, R., E. Korejwo (red.), Dolnośląska Agencja Współpracy Gospodarczej, Wrocław.

\footnotetext{
2 Według danych OECD, udział nakładów na B+R w Czechach i na Wegrzech w latach 2004-2014 wzrósł odpowiednio: z 1,15\% do $2 \%$ i z $0,86 \%$ do $1,37 \%$. W Polsce wskaźnik ten w tym czasie wzrósł z poziomu $0,56 \%$ do $0,94 \%$, czyli o 0,38 p. p. [Gross domestic spending on R\&DD].
} 
Dziemianowicz R., 2015, Istota i definicja taxexpenditures - aspekt teoretyczny, [w:] Tax expenditures jako narzedrie transparentnejpolityki fiskalnej. Definiga, szacowanie i ocena, R. Dziemianowicz (red.), Wydawnictwo CeDeWu, Warszawa.

Europa 2020. Strategia na rzecz inteligentnego i zrównoważonego rozwoju sprayjajacego właczeniu społecznemu, Komunikat Komisji $\operatorname{KOM}(2010)$, 2020, wersja ostateczna, Komisja Europejska, Bruksela, 3.3.2010, http://eur-lex.europa.eu/LexUriServ/LexUriServ. do?uri=COM:2010:2020:FIN:PL:PDF (data wejścia: 16.11.2016).

Gross domestic spending on R\&D, https://data.oecd.org/rd/gross-domestic-spendingon-r-d.htm (data wejścia: 16.11.2016).

Nanka i technika w 2014 r., 2014, Główny Urząd Statystyczny, Warszawa, http:/ / stat.gov.pl/ obszary-tematyczne/nauka-i-technika-spoleczenstwo-informacyjne/nauka-i-technika/ nauka-i-technika-w-2014-r-,1,11.html (data wejścia: 14.08.2016).

Preferencje Podatkowe w Polsce, http:/ /www.finanse.mf.gov.pl/abc-podatkow/preferencjepodatkowe-w-polsce (data wejścia: 16.11.2016).

Ustawa z dnia 15 lutego 1992 roku o podatku dochodonym od osób prawnych, Dz. U. 1992, Nr 21, poz. 86 z późn. zm.

Ustawa z. dnia 25 września 2015 roku o zmianie niektórych ustaw w zwiqzku ze wspieraniem innowacyjności, Dz. U. 2015, poz. 1767.

Ustawa z dnia 26 lipca 1991 roku o podatku dochodonym od osób firycznych, Dz. U. 1991, Nr 80, poz. 350, z późn. zm.

Wildowicz-Giegiel A., Dziemianowicz R., 2015, The impact of tax incentives on the proces of innovation creation in Polish economy, Proc. of the Third Intl. Conf. Advances in Social Science, Economics and Management Study, Institute of Research Engineers and Doctors, USA.

Worldwide ReDD incentives reference guide 2014-15, http://www.ey.com/Publication/ vwLUAssets/EY-worldwide-randd-incentives-reference-guide/\$FILE/EYworldwide-randd-incentives-reference-guide.pdf (data wejścia: 05.08.2016).

Zalecenie Komisji 2003/361/WE z dnia 6 maja 2003 roku dotyczqce definicii przedsiebiorstw mikro, matych i średnich, Dz. U. UE L 124, 20.5.2003.

Zegarowicz L., 2016, Wplyw systemu podatkowego na innowacyjność gospodarki na prayktadzie Polski i wybranych krajów, praca magisterska przygotowana pod kierunkiem dr. hab. R. Dziemianowicz, prof. UwB, Katedra Skarbowości, Wydział Ekonomii i Zarządzania, Uniwersytet w Białymstoku, obroniona 12.07.2016, Białystok.

Zuzek D. K., 2014, Polityka pañstwa wobec wspierania driałalności innowacyjnej matych i średnich przedsiebiorstw w Polsce na prayktadzie województwa małopolskiego, „Roczniki Naukowe”, t. XVI, z. 1, Stowarzyszenie Ekonomistów Rolnictwa i Agrobiznesu. 